\title{
Editorial: Avian Research
}

\author{
Yong Wang ${ }^{1 *}$ and Guangmei Zheng ${ }^{2}$
}

Welcome to Avian Research! This new journal is a continuation and enhancement of Chinese Birds, which has been and continues to be sponsored by the China Ornithological Society and Beijing Forestry University. In the four years since its inception, the original journal the only one in China focusing on avian research - has published over 130 manuscripts, with authors from all continents across the world, garnering global respect in the avian research community. We are grateful to the authors who have contributed to this journal and the reviewers for their professional and thoughtful inputs to help the journal to achieve its high standards.

Change of title of our journal emphasizes one of the primary missions of the original journal: to be the first ornithological professional publication in China with a broad international focus. This change is based on suggestions and feedback from ornithologists and readers from across the world and through many discussions held among members of the editorial board of the journal and the China Ornithological Society. We hope this change will further improve its international outreach and reception. China has diverse and unique avian resources and an immanent importance for the worldwide avian biodiversity conservation. With recent economic development and scientific advances, ornithology as a field and career focus has faced a dramatic growth in the past thirty years in China. We are taking on increasingly complex questions and advances in technology; international collaboration is playing an ever increasing critical role for avian research in China and in the world. It is our hope that this new title will facilitate exposure of the journal and attract a more global audience.
The new journal will continue to publish peerreviewed articles and reviews, covering all areas of ornithology, basic or applied. Methodology articles, which address issues related to avian research methods that are field, lab, or analytical related, are also welcome. We have a particular interest in promoting and publishing studies concerning the birds of Asia. Although Asia has some of the most diverse avian communities in the world and has experienced some of the greatest economic growth in recent history, avian research in this region is less active and not as well-exposed to an international audience as compared to other regions in the world.

We are honored to have a diverse Editorial Board with reputable experts from China and other countries. Avian Research will continue to enhance its service and delivery through new initiatives. The editorial board will be more involved through activities such as organizing special issues and serving as guest editors. To facilitate access of the journal by a global audience and to reduce turn-around time for the publication process, Avian Research will conduct its business mostly online through BioMed Central, an established scholarly publishing platform. We will strive to minimize the time interval between submission receipt and final publication by making the decision of acceptance for review within one week of submission and the decision for publication within the following two months. Accepted articles will be posted immediately after the completion of the editorial proofing. Posted articles will have DOI and article numbers for citation. Authors may request offprints of their published manuscripts from the editorial office if they desire. The publications will be available at the

\footnotetext{
* Correspondence: wang.aamu@gmail.com

${ }^{1}$ Department of Biological and Environmental Sciences, Alabama A\&M

University, Normal, AL 35762, USA

Full list of author information is available at the end of the article
}

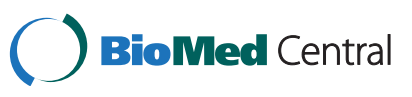

(c) 2014 Wang and Zheng; licensee BioMed Central Ltd. This is an Open Access article distributed under the terms of the Creative Commons Attribution License (http://creativecommons.org/licenses/by/4.0), which permits unrestricted use, distribution, and reproduction in any medium, provided the original work is properly credited. The Creative Commons Public Domain Dedication waiver (http://creativecommons.org/publicdomain/zero/1.0/) applies to the data made available in this article, unless otherwise stated. 
journal website www.avianres.com, and readers may subscribe email-alerts to be informed of newly released articles. The page charge will continue to be waived for all authors for the first three years of the new journal. Our goal is for Avian Research to be a high quality, user-friendly, and easily accessible journal that helps to advance human knowledge of birds and science, in general, in China and globally.

\section{Author details}

'Department of Biological and Environmental Sciences, Alabama A\&M University, Normal, AL 35762, USA. ${ }^{2}$ College of Life Sciences, Beijing Normal University, Beijing 100875, China.

Received: 29 July 2014 Accepted: 5 August 2014 Published: 23 September 2014

\section{Submit your next manuscript to BioMed Central and take full advantage of:}

- Convenient online submission

- Thorough peer review

- No space constraints or color figure charges

- Immediate publication on acceptance

- Inclusion in PubMed, CAS, Scopus and Google Scholar

- Research which is freely available for redistribution 